\title{
California Ground Water: Legal Problems
}

\author{
Wells A. Hutchins*
}

I

\section{BASIC CALIFORNIA DOCTRINES OF GROUND WATER RIGHTS}

The California law of ground water rights is primarily judicial. For more than a half-century, the courts in many decisions have created and developed the current rules that govern the water rights in the vast developments of ground waters in this state and, with marked consistency, the legislature has followed a hands-off policy. It is true that some statutes relate to ground water, but they bear no resemblance to a ground water code.

In California, the historic legal distinction between percolating waters and definite underground streams is observed by both the legislature and the courts. ${ }^{1}$ Subterranean waters are percolating if they are not concentrated in channels with definite beds and banks and are not moving in defimite streams. And waters broadly diffused through loose water-bearing materials in well-defined subterranean basins, whether or not under artesian pressure, are percolating waters, not those of defimite streams. ${ }^{2}$ However, riglits to the use of percolating waters are currently governed by rules of law that are very similar to those relating to definte streams. That is, the riparian and appropriation doctrines apply to both surface and underground watercourses, and the correlative and appropriation doctrines apply to percolating ground waters-correlative ground water rights being analogous in many respects to riparian stream water rights.

The law presumes that ground waters are percolating. ${ }^{3}$ Hence, a person who asserts the existence of a definite subterranean stream has the burden of proving it, and the practical difficulties in making such proof are considerable. One who wishes to appropriate ground water under the procedure in the Water Code-which applies only to definite streams-or who seeks to have his ground water rights adjudicated under the complete statutory procedure-which also relates only to definite streams-is under this burden. ${ }^{4}$ But aside from these positive statutory requirements, developments

*Attorney, Farm Economics Research Division, Agricultural Research Service, United States Department of Agriculture, Berkeley.

${ }^{1}$ See Cax. WaTer Code $\$ \S 1200,2500$; Cave v. Tyler, 147 Cal. 454, 456, 82 Pac. 64, 65 (1905) ; Vineland Irrigation Dist. v. Azusa Irrigating Co., 126 Cal. 486, 494, 58 Pac. 1057, 1059 (1899); Los Angeles v. Pomeroy, 124 Cal. 597, 633-34, 57 Pac. 585, 598 (1899).

2 Katz v. Walkinshaw, 141 Cal. 116, 138-40 (on rchearing, opinion on carlier hearing reprinted, 70 Pac. 663, 664-65 (1902) (original hearing), 74 Pac. 766 (1903) (rehearing).

3 Los Angeles v. Pomeroy, 124 Cal. 597, 628, 633-34, 57 Pac. 585, 596, 598 (1899).

4 CAL. WATER CODE $\$ \S 1200,2500$. 
during the present century have tended to lessen the necessity for making such proof. Among such developments are (1) the adoption in Katz v. Walkinshaw $w^{5}$ of the rules of reasonable use and correlative rights in place of that of absolute ownership of underlying water; (2) the adoption, in 1928, of a constitutional amendment as a result of which the use of all water, under whatever right the use may be enjoyed, is restricted to reasonable beneficial use under reasonable methods of diversion and use; ${ }^{6}$ (3) the closer coordination of rights in surface and ground water supplies than existed previously; ${ }^{7}$ (4) the extensive developinents of ground waters that were conceded or assumed to be percolating; and (5) the development, chiefly with respect to percolating water, of a large body of Cabifornia case law governing rights to the use of ground waters.

The basic rules that now govern rights to the use of percolating water are called the California correlative doctrine, or doctrine of correlative rights. As with the riparian doctrine of surface water rights, rights of use under the correlative doctrine are based on location of the land in relation to the water supply. That is, owners of all lands that overlie a supply of percolating water have correlative or co-equal rights to the use of the water, just as have the owners of riparian lands in the waters of the streain to which their lands are contiguous.

The water rights that relate to a well developed supply of percolating water may be in three categories: ${ }^{8}$

First are the original rights which by judicial fiat, were an integral part of the overlying lands when the lands passed to private ownership and which have renained so unless divested by some legal process such as grant, prescription, or condemnation. These rights entitle all owners to abstract and use the ground water on or in connection with their overlying lands to the full extent of their reasonable beneficial needs, as long as the water supply is enough for all. If the water supply is insufficient to satisfy all reasonable needs, it niay be apportioned on some equitable basis by court order. No overlying owner has priority over any others solely because he used the water first.

6141 Cal. 116, 74 Pac. 766 (1903).

6 CaI. Const. art. XIV, § 3; Peabody v. Vallejo, 2 Cal. 2d 351, 367-68, 372, 383, 40 P.2d 486, 491, 494, 498-99 (1935).

7 Katz v. Walkinshaw, 141 Cal. 116, 134-37, 74 Pac. 766, 771-73 (1903) ; Larsen v. Appollonio, 5 Cal. 2d 440, 444, 55 P.2d 196, 198 (1936); Peabody v. Vallejo, 2 Cal. 2d 351, 372, 40 P.2d 486, 494 (1935); Hudson v. Dailey, 156 Cal. 617, 628, 105 Pac. 748, 753 (1909); Cohen v. La Canada Land \& Water Co., 142 Cal. 437, 439-40, 76 Pac. 47, 48 (1904); McClintock v. Hudson, 141 Cal. 275, 281, 74 Pac. 849, 851 (1903); Eckel v. Springfield Tunnel \& Development Co., 87 CaI. App. 617, 622-25, 262 Pac. 425, 427-28 (1927).

8 Pasadena v. Alhambra, 33 Cal. 2d 908, 925-27, 207 P.2d 17, 28-29 (1949); see Burr v. Maclay Rancho Water Co., 154 Cal. 428, 435-37,. 98 Pac. 260, 263-64 (1908); Katz v. Walkinshaw, note 7 supra. 
Second are rights that may attach, by priority of appropriation for nonoverlying uses, to any surplus that may exist in the ground water supply above the lawful requirements of the overlying owners. An appropriation of percolating water is accomplished solely by diversion and use, not by following any procedure in the Water Code. As long as there is a surplus in the ground water area, appropriative rights relating to such surplus are just as valid and entitled to protection as are the rights of overlying owners in the non-surplus. Such appropriations may be made for the use of the water outside the ground water area, or for public utility use within the area.

Third are appropriative rights that have become prescriptive as the result of invasion of the rights of overlying owners or prior appropriators, or both. An appropriative taking of surplus water above the requirements of overlying owners, or of such owners and prior appropriators, is lawful and hence not adverse. But a taking of non-surplus water is unlawful and adverse, and may, if continued, ripen imto a prescriptive right.

The impact of the law of prescription upon water rights in an overdrawn ground water area resulting from the California supreme court's decision in Pasadena v. Alhambra - the Raymond Basin case- ${ }^{2}$ calls for some consideration at this point. The elements of prescription that determine the ripeming of an adverse ground water right are the same as those that relate to surface waters, but in some respects the applications differ. For example, the saying that "prescription does not run upstream" is true in probably most cases of adverse use of stream waters in which actual trespass on upper lands or works is not involved. But the effect of heavy pumping of percolating water is not merely to intercept the flow of the water in its process of seeking a lower level, but is to draw water away from other parts of the area in several and possibly all directions, and to lower the water table withm the area of pumping influence. Furthermore, in the case of a surface stream, the injury that gives rise to a cause of action is the actual deprivation of water, or the prevention of access to it, resulting from the adverse taking. In a ground water area, on the other hand, the adverse taking does not immediately have this effect. The water is still available, and for a long time it may be possible to continue to pump the accustomed quantity, although with an increasingly higher lift. Here, as it was held in the Raymond Basin case, the cause of action accrues at the commencement of overdraft, because that is when the rights of overlying owners and prior appropriators are first invaded. It is a present invasion, the full effects of which will be felt in the future. In the words of the California supreme court, the injury "consisted of the continual lowering of the level and gradual reducing of the total amount of stored water, the accumulated effect of which,

${ }^{9} 33$ Cal. 2d 908, 928-29, 931-32, 207 P.2d 17, 30, 31-32 (1949). 
after a period of years, would be to render the supply insufficient to meet the needs of the rightful owners." 10

In the Raymond Basin case the supreme court held that the appropriations that caused the overdraft were invasions, to some extent at least, of the superior overlying and appropriative rights, and that they initiated the acquiring of prescriptive rights against the latter. But the original holders of water rights continued to pump, notwithstanding the overdraft and the invasions of their superior rights. By so doing, they either retained or acquired rights to continue to take some water in the future. For the purpose of this adjudication, the supreme court found it unnecessary to determine whether the overlying owners simply retained a part of their original overlying rights, or whether they obtained new prescriptive rights to use the water. By the decree, all parties were restricted to a proportionate reduction in the quantities of water they had been pumping, the total annual pumpage from the basm being limited to the safe yield.

II

\section{BASIC DOCTRINES: SOME DIFFICULTIES}

Despite the long period during which the basic Califorma doctrines relating to rights of overlying owners and appropriators in percolating waters have been developed, and their facets amplified and applied to the facts of litigated cases, difficulties and uncertainties remam. No more will be attempted than to hist and comment briefly on some of them.

The legislature has excluded percolating water supplies from those from which appropriations may be made under the statutory procedure. This exclusion was first made in the original Water Commission Act of $1913,{ }^{11}$ and it is continued in the Water Code. ${ }^{12}$ As a result, one inust file an application to appropriate ground water if it is flowing through a known and definite channel, but not if it is percolating water; and the State Water Rights Board may reject an application if it becomes apparent that the requisite channel does not exist..$^{13}$ One who installs or deepens a water well is required by statute to report its completion to the appropriate regional water pollution control board; $;^{14}$ and in 1955 the legislature provided for the recordation with the State Water Rights Board of certain ground water extractions in five counties in the southern part of the state.$^{15}$ Otherwise, there is no pro-

10 Id. at 929,207 P.2d at 30.

11 Cal. Stat. 1913, c. 586, § 42.

12 CAI. WATER CODE $\$ 1200$.

13 Cax. Dep't of Public Works, Rules, Regulations and Information Pertatnitg to APpropriation OF WATER IN CALIFORNIA 40-41 (1956).

14 CAL. WaTER CODE $\$ \S 7076-78$.

15 Id. $\S \S 4999-5008$. 
vision for public records of the essential data on which to establish and defend an appropriation of percolating water. Granted that overdrafts are common, and that in many areas there now may be little or no surplus water to appropriate, opportunities for obtaining prescriptive appropriative rights are doubtless considerable.

Likewise, while the court reference procedure may include rights to the use of percolating water-and lias done so in the important Raymond Basin and West Coast Basin ${ }^{16}$ references-the statutory adjudication procedure cannot include ground water rights other than those relating to water flowing in known and defimite channels. ${ }^{17}$ The physical interrelationships between stream waters and percolating ground waters are well known. For decades, decisions of the Califorma supreme court have recognized this situation, and have coordinated rights relating to the several parts of such common water supplies. ${ }^{18}$ Yet a statutory adjudication proceeding, in determining all riparian and appropriative riglits that attach to a stream system, cannot extend to riglits in percolating waters that feed the stream, or to those that liave escaped from it. Of course, exclusion of percolating water from the Water Code procedures for appropriation and for statutory determination is subject to clange by the legislature.

The first holding by the supreme court to the effect that in an overdrawn ground water basin the statute of limitations begins to run when the overdraft first occurs was in Pasadena v. Alhambra. ${ }^{10}$ Necessarily, if prescriptive rights in such water supplies are to be recognized, there must be adverse use for a period of five years, and that period must have a definite beginning. Assuming the soundness of the supreme court's reasoning in holding that the invasion of the superior right begins at the commencement of overdraft, nevertheless the effect is to cast upon the overlying owner or prior appropriator the burden of recognizing the inception of overdraft and, if his right is to be preserved in full, to take court action within the ensuing five years. Public entities or group organizations may have the facilities for ascertaining the pliysical situation within reasonable limits, but an imdividual does not.

One of the difficulties in administering rights to the use of pumped water is the amount of supervision that may be required. The problem of policing an area containing hundreds of individual pumping plants is not as simple

${ }^{16}$ Still pending as Los Angeles Super. Ct. No. 506806. The pleadings are under the name California Water Service Co. v. Compton or California Water Service Co. v. Abercrombie.

17 Cas. Water CoDE $\$ \$ 2000-01,2500$.

18 Lodi v. East Bay Mumicipal Util. Dist., 7 Cal. 2d 316, 337-43, 60 P.2d 439, 448-51 (1936) ; Miller v. Bay Cities Water Co., 157 Cal. 256, 272, 278-81, 107 Pac. 115, 122, 124-26 (1910); Hudson v. Dailey, 156 Cal. 617, 628, 105 Pac. 748, 753 (1909) ; McClintock v. Hudson, 141 Cal. 275, 281, 74 Pac. 849, 851 (1903).

1933 Cal. 2d 908, 207 P.2d 17 (1949). 
as that of regulating headgates on a surface stream. Enforcement of ground water rights determined by court decree or by agreement of the parties may require a considerable operating force and a large budget.

\section{III}

\section{BASIC DOCTRINES: SOME UNCERTAINTIES}

An appropriator of either surface or ground water is entitled to protection, as against other appropriators, in the use of reasonable means of diversion. This is the general rule in the West, and it has been applied in California. In several cases in this state the rule has been declared that a prior appropriator must use reasonably efficient appliances in making his diversion, in order not to deprive others of the use of the surplus water $;^{20}$ and that he may be subjected to some mconvenience or extra expense within limits that are not unreasonable, but cannot be required to suffer substantial damage ${ }^{21}$ nor incur material expense in order to accommodate a subsequent appropriator. ${ }^{22}$ The case of Lodi $v$. East Bay Municipal Util. Dist. ${ }^{23}$ involved rights of the City of Lodi in a ground water supply fed by percolations from the Mokelumne River. The city was a prior appropriator of such ground waters, by pumping from wells. The defendant district was a junior appropriator of water of the river, with a point of diversion upstream from the area in which the percolating waters escaped from the river. The supreme court held that under existing conditions the city's diversion was reasonable, and applied the rule just stated. But does the same rule apply as between owners of land overlying a ground water basin in the exercise, not of appropriative, but of overlying correlative rights? Are such owners, who have not yet used any of the water, precluded from access to the supply for reasonable beneficial use on their overlying lands solely because such abstraction and use may force other owners in the basin, who are presently using the water, to deepen their existing diversions? Inasmuch as priority in time of beginning use of the water is not a factor as between users on overlying lands, should there be priority in the means of diversion, which is essentially a means of effectuating use? The decisions accord to all landowners co-equal rights in the common supply, and they do not predicate these rights on the portion of the water supply that is available at the depth at which the first user encounters it. In several cases, overlying owners have been protected against lowering of the water table by appropriative takings for distant use, but, as between overlying owners, there are no decisions squarely in point.

20 E.g., Natoma Water \& Min. Co. v. Hancock, 101 Cal. 42, 51-52, 35 Pac. 334, 337 (1894).

21 E.g., Peabody v. Vallejo, 2 Cal. 2d 351, 376-77, 40 P.2d 486, 495-96 (1935).

22 E.g., Tulare Irrigation Dist. v. Lindsay-Strathmore Irrigation Dist., 3 Cal. $2 \mathrm{~d} 489$, 572-74, 45 P.2d 972, 1009-10 (1935).

23 ᄀ Cal. 2d 316, 60 P.2d 439 (1936). 
Another uncertainty in this category relates to the remedy, if any, of an owner of overlying land just within the shallow rim of a deep basin, who has used the ground water for a long time, but from whose land all the water has now been drained by reason of extensive developments by deep pumping on lands farther out in the basin. Assuming that the overlying uses by all parties are reasonable and beneficial, and that ample water is in storage in the center of the basin, does the correlative right of the early user at the rim entitle him to compel those farther out to pump less water than is necessary for their own reasonable beneficial needs, or, at their own expense, either to supply him with water from their own wells or to provide him with a pumping plant in the central area? Here again, the precise question apparently has not been decided in the appellate courts.

Complications may arise also in situations that involve adding to the gromd water supply rather than decreasing it. For example, under the Water Code, water may be appropriated for the purpose of spreading over land for subsequent recovery for beneficial use. ${ }^{24}$ Does the rule that permits the utilization of a surface channel to convey water and to recover it, minus losses, as against other claimants of rights in the stream, apply to water discharged into the ground and thence percolating through the sub-strata of land owned by an individual who has had no part in the spreading operations, but who pumps the water for use on his overlying land? Of course, control by the same interests of the entire project-recharging grounds, recovery operations, and intervening private lands-takes care of this question. And benefits to land from the replenishment of ground water supplies resulting from surface irrigation on other lands can be assessed by a district of appropriate type.

In Pasadena v. Alhambra, ${ }^{25}$ the supreme court left unsettled the question whether the overlying owners and prior appropriators, by continuing to pump during the periods in which prescriptive rights were being acquired against thein, thereby retained part of their original rights, or whether they acquired new prescriptive rights to pump water. A decision on that point was not considered necessary in determining the issues. In some future case, it may become necessary to decide it.

\section{WHAT OF THE FUTURE?}

The principles of law that govern rights to the use of percolating waters in California have been developed both in contests between overlying owners and in actions brought by individuals or groups of overlying owners to prevent organized groups from taking the ground water for non-overlying purposes. The taking may have been either for the purpose of exporting

24 CAL. WATER CODE $\$ 1242$.

2533 Cal. 2d 908, 207 P.2d 17 (1949). 
the water for distant use, or for use by means of public utility service within the area. A private water company, municipality, or district that pumps ground water and distributes it within the ground water area on a public utility basis ${ }^{26}$ does not act in the capacity of an overlying owner, nor is it substituted to the use of the private correlative rights of overlying landowners to whoin it may serve the water unless, by legal process, it has acquired the rights for use on such lands. The public service organization, whether privately-owned or a public entity, is an appropriator of the ground water for public use-a non-overlying purpose-and in time its water rights may become prescriptive against some or all of its consumers. ${ }^{27}$ In most cases of this character, the public service covered only a part of the ground water area, and the rights that were involved were the correlative rights of overlying owners and the appropriative or appropriative-prescriptive rights of the utilities. With respect to mutual company service, it is true that in southern California, particularly, ground water has constituted a large part of the water served by important enterprises of this type to their stockliolders. But takmg the state as a whole, the enornous aggregate developments of percolating water up to this time have consisted chiefly of individual enterprises on individual farms.

For many decades, the trend with surface water projects has been toward group or public financing and construction. In view of the magnitude and cost of the work involved, this trend has been inevitable. And so, as time goes on, it seems likely that individual rights to the use of water supplies now undeveloped will be to a lesser extent those of appropriators and riparian owners, and to a greater extent rights to the service of water represented either by contracts with service organizations, or by inclusion of the lands within public districts, formal title to the basic appropriative rights being held by the distribution agencies or by entities under contract with them.

With respect to ground water, one may visualize extensive group action for protecting, controlling, and supplementing existing private developments. But in considering group possibilities in the handling of ground water, it is necessary to keep in mind how firm is the doctrine of correlative rights in California, where it has been litigated and affirmed and its facets expounded by the high courts over and over again throughout a period of fifty-five years, with all that that inplies. The landowner's correlative right is good not only for present use, but also for future use on the overlying land; and one not presently using water, but who does not wisl to forego the right of future use, nay have it protected by declaratory decree against

26 Burr v. Maclay Rancho Water Co., 160 Cal. 268, 280, 116 Pac. 715, 721 (1911).

27 Pasadena v. Alhambra, 33 Cal. 2d 908, 927, 207 P.2d 17, 29 (1949); Eden Township County Water Dist. v. Hayward, 218 Cal. 634, 638-41, 24 P.2d 492, 494-95 (1933). 
loss by prescription. ${ }^{28}$ Like other water rights, the individual correlative right is a right of private property. Although doubtless subject to regulation under the police power, it obviously cannot be taken or impaired without due process of law. Hence, if the landowner is vigilant in protecting his water right against infringement by adverse use, group action must either have his concurrence, or must be implemented by condemnation.

Granted that due process is provided for, collective action can accomplish many things that are becoming increasingly important to the ground water user, but that are beyond his capacity as an individual. These matters include ascertainment of the physical factors relating to the origin, direction of movement, rate of flow, and safe yield of the supply, and up-to-date information on conditions affecting overdraft; management of ground water supplies-their controlled depletion and replenishment in the interests of their best utilization, efficiency, and safety; augmentation of inadequate supphes by importations of surface water both for direct use and for spreading; and representation in court. Some of these matters can be handled by private cooperative enterprises in which the water users hold shares of capital stock. Others require the functions of an organization that may exercise the power of eminent donnain, or that in addition has the power of taxation and access to large capital. For several generations, while local sources of water were available and adequate, the inutual water companies in the south managed them with their own corporate powers. But when it becaune necessary to supplement diminishing supplies with large importations from a distant source, resort was had to the public district form of organization.

The courts of Texas still adhere to the old theory of ownership by the overlying landowner of the percolating water while it is in his land ${ }^{20}$ In the face of this, in attempting to meet the problem of overdevelopment, the Texas legislature has gone as far as it was deemed constitutionally possible to go by providing a form of district organization in which ownership and rights of the landowner in ground water are specifically recognized, but which is empowered to promulgate rules and regulations for the prevention of waste. ${ }^{30}$ The district may plan and carry out projects for artificially recharging ground water reservoirs; and it has certain powers with respect to issuance of permits to drill wells, to provide for their proper spacing,

28 Burr v. Maclay Rancho Water Co., 160 Cal. 268, 281-82, 116 Pac. 715, 722 (1911).

29 Corpus Christi v. Pleasanton, 154 Tex. 289, 292-94, 276 S.W.2d 798, 800-02 (1955); see Houston \& T. Cent. Ry. v. East, 98 Tex. 146, 149-50, 81 S.W. 279, 280-81 (1904) ; Cantwell v. Zinser, 208 S.W.2d 577, 579 (Tex. Civ. App. 1948); see also Greenhill and Gee, Ownership of Ground Water in Texas: The East Case Reconsidered, Proc. U. TEx. WaTER LAw ConfERENCE 61 (1955), 33 TEXAS L. REv. 620 (1955).

30 TEx. REv. CIv. Stat. art. 7880, § 3c (Vernon Supp. 1950). 
and to regulate the production of water from them. In the High Plains area, districts have been formed and are operating under this act. ${ }^{31}$

California has a wide range of enabling acts under which districts may be formed for various purposes relating to water..$^{32}$ Functions of some relate to control of ground waters. Two recent informative articles by Stephen $\mathrm{C}$. Smith deal with the situation in Cahifornia-in which public districts have carried out ground water replenishment activities for more than a quartercentury-with particular reference to experiences in the Santa Clara Valley. ${ }^{33} \mathrm{He}$ points out that althougll use of the public district for ground water management, and for integrated management of surface and ground waters, is beset with difficult problems, experience shows that the district can play a useful role in this field. Harvey O. Banks, now Director of the California Department of Water Resources, in an address in 1953, said: ${ }^{34}$

The need for planned utilization of ground water basins in the future seems fairly obvious if we are to achieve full conservation of our available water supplies at reasonable cost.

As already stated, physical relationships between surface and ground waters have long been widely recognized and, for decades, the California courts have recognized the legal relationslips with respect to natural sources. In the further development of our water economy, planned management and integration seem not only desirable, but essential. Organization of course is necessary; forms of organization, including the public district, are available.

31 Duggan, Rights in Ground Water in Texas, Proc. U. Tex. Water LaW CoNference 72 (1955) ; Duggan, Texas Ground Water Law, Proc. 1952, 1954 U. Tex. Water LAW ConferENCE 11 .

32 Cat. Dep't of Publtc Works, Div. of Water Resources, Generat Comaparuson of CaLIFornia Water District Acts (1955).

33 Smith, Problems in the Use of the Public District for Ground-Water Management, 32 Land Econ. 259 (1956) ; Smith, The Role of the Public District in the Integrated Management of Ground and Surface Water, WeStern Agricutturai Researce Councr. ComantTeE on the Econouncs of Water Resources Devejopment Report No. 5, Ground Water EcoNOMCTCS AND THE LAW 81 (1956).

34 Banks, Problems Involved in the Utilization of Ground Water Basins as Storage Reservoits, Proc. 26th Annuai Convention Assoc. Western State Engineers 91, 92 (1953). 